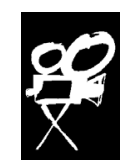

Studia

Filmoznawcze

Wrocław 2017

\title{
Marek Paryż
}

University of Warsaw

\section{A MAP OF LONGINGS: UTOPIAN UNDERPINNINGS OF CONTEMPORARY TRANSNATIONAL WESTERNS}

DOI: 10.19195/0860-116X.38.10

This paper examines the utopian implications of three post-2000 transnational Westerns with respect to the creation of political subtexts of the films. The titles to be discussed include: My Sweet Pepper Land, a French-German-Iraqi co-production (Hiner Saleem, 2013), Dust, a Macedonian-German-British-Italian co-production (Milcho Manchevski, 2001), and Blackthorn, a French-Spanish-American-Bolivian co-production (Mateo Gil, 2011). The common denominator of these three films, which obviously emerge from different cinematic traditions and refer to different contexts, is the employment of the narrative schema of the Western as a way of problematizing contemporary political issues. A concomitant presence of the utopian mode accounts for the capacity and relevance of the generic paradigms of the Western as an artistic expression of various political and cultural anxieties of today. When analyzed together, My Sweet Pepper Land, Dust and Blackthorn show that the Western genre allows for a plethora of formal possibilities that can be adjusted to strikingly heterogeneous contexts. Thus, My Sweet Pepper Land, is set in the contemporary time and unfolds in accordance with the archetypal story of a brave and upright lawman who establishes order in an isolated borderland town. Such a plot construction does not undermine the film's realism. In turn, Dust resorts to the postmodern techniques of narrative mediation with an aim to construct a contemporary perspective on a historical situation. The reinvented past then suggests questions as 
to specific political ideas of the present day. Finally, Blackthorn is a historical film which does not touch upon any contemporary problems directly. However, it does engage in a dialogue with the issues of the present time through analogy. All the three films revolve around the themes of community, oppression and intervention, which is not surprising, given their genre. The necessity of interventionism postulated by the films under discussion draws our attention to the manifestations of contemporary forms of injustice and to the ways in which they have been historically conditioned. At the same time, the presence of utopian underpinnings testifies to the awakening of a social/political consciousness, an indispensable first step on the way to overcoming the state of oppression, injustice or exploitation.

Traditionally understood as a genre based on a fantasy projection of a better world, utopia has recently undergone a thorough redefinition. Current scholarship understands utopia as comprising a multitude of ideologically charged narrative variants which may appear to lack the generic specificity of the utopia, but at a closer inspection prove to convey utopian meanings by offering a reassessment of a current or historical state of affairs through a reference to some kind of "vision." Philip E. Wegner writes with respect to narrative utopias that they "conceive of the present in terms of the future, as something that is incomplete and continuously coming into being." Therefore, "the present, its concerns, desires, and contradictions, rather than being the end of the representational practices of the narrative utopia... serves as the very raw material from which the narrative performance will generate something original" (xix). Jay Winter offers a convincing description of the narrative logic behind utopia as this logic is now understood. He calls utopia "a discourse in two contradictory parts": on the one hand, "it is a narrative about discontinuity... a story through which men and women imagine a radical act of disjunction, enabling people, acting freely and in concert with others, to realize the creative potential imprisoned by the way we live now," but on the other hand, "since the narrative is written by men and women rooted in contemporary conditions and language, it inevitably shows where they are, even as it describes where they want to be." Winter suggests that it is precisely the aspect of unreality that produces the subversive potential of utopia: "Utopia... is a fantasy about the limits of the possible, a staging of what we take for granted, what is left unsaid about our current social conventions and political cultures. Those who expose these silences, often playfully, begin to disturb the contradictions in the way we live" (3-4). Of particular significance for the discussion of the three film Westerns presented in this article - as they all focus on the experience of nations that had been confronted with colonial hegemony is Winter's distinction between "major utopias," which have been discredited by twentieth-century totalitarian regimes, and "minor utopias," which are "imaginings of liberation" and fulfill crucial cultural functions (4-5).

In his seminal book Gunfighter Nation: The Myth of the Frontier in TwentiethCentury America, Richard Slotkin has differentiated two political styles that from 
the late nineteenth century onward have been shaping the frontier myth and its literary and cinematic versions: the "progressive" and the "populist." The former advocates a corporate economy and promotes a managerial outlook; it defines growth as expansion, insists on a parallel process of the strengthening of political institutions and identifies a privileged class of the leaders of progress. By contrast, the latter style postulates economic individualism and broader access to political power enabled by a common right to ownership. It views modernization as a possible threat to the democratic structure of society. Slotkin adds that these two styles share an ideological core and are not mutually exclusive (22-24). Although Slotkin's discussion concerns a completely different context, it helps to understand the ways of encoding utopian meanings in the three films analyzed in this article. The films reinvent the categories of progressivism and populism on their own terms, but this dichotomy, in a considerable degree, determines their ideological implications. As a matter of fact, if the convention of the Western is used to address directly or indirectly current political issues in varied global circumstances, the progressive and the populist styles may be inherent options for such a kind of artistic engagement. Both these styles are connected to utopian thinking insofar as they enable the articulation of the longings prevalent in a given population at a certain time. Indeed, a combined analysis of My Sweet Pepper Land, Dust and Blackthorn allows one to reconstruct a representative fragment of the map of national longings in the present global era.

The notion of utopia as "a means of mapping the world" appears in Robert T. Tally's book Utopia in the Age of Globalization. Tally writes that "the utopian impulse reflects an effort to situate oneself in space and in history, imaginatively projecting a world that enables one to represent the apparently unrepresentable totality of the world system." Such imaginative acts function analogously to "literary cartography": "the artist or critic produces an imaginary, even fantastic, image of the space to be represented, developing a more or less useful tool for apprehending the world in which we live, and thereby perhaps inviting considerations of alternative maps." Tally concludes that "[t]he utopian practice is not... epistemological, offering a means of knowing the world, but literary, allowing us to tell stories in different ways as means of representing ourselves and the world in the present time and space" (ix-x; original italics). The utopian impulse toward figurative mapping, as described by Tally, certainly underlies the three films under discussion, but they rely on a different conception of "the world system." For Tally, the world system should be equated with the existence of a supranational economic space, not unlike Michael Hardt and Antonio Negri's Empire, which "progressively incorporates the entire global realm within its open, expanding frontiers... [and] manages hybrid identities, flexible hierarchies, and plural exchanges through modulating networks of command" (Hardt and Negri xii-xiii). The films presented in this article, conversely, associate the world system with a hierarchy of values and symbolically 
identify the West as its source. Even if they explicitly deal with the problem of the local distribution of political or economic power, they are also concerned with values which the West as a mythologized intellectual construction supposedly epitomizes. It is specific values - overtly political as well as deeply philosophical, thus dramatically affecting individual attitudes - that inform the utopian scenarios projected by the transnational Westerns under discussion. My Sweet Pepper Land builds its utopian subtext on the idea of liberalism, Dust generates utopian implications through a dialogue with the notion of sovereignty, and Blackthorn envisages a utopia that begins with an act of enfranchisement through ownership.

\section{THE UTOPIA OF LIBERALISM}

My Sweet Pepper Land, advertised as a Kurdish Western, begins with a grotesque scene of execution: after the elections following the fall of Saddam Hussein, the first execution is treated by those who attend it as an important event in a series of the foundational acts of autonomous Iraqi Kurdistan. The officials and the policemen responsible for the execution are unexpectedly faced with a very practical dilemma: there is no gallows. They decide to use a protruding rod, which breaks off under the criminal's weight, and then the supporting structure of a basketball hoop; the second attempt is successful. The vision of a great future of a new democratic nation, proudly articulated by one of the officials, is starkly at odds with the combination of awkwardness and brutality that characterizes the policemen's actions. This disparity between the vision, imaginings or longings and the crude reality defines the time of transition depicted in the film. Transition breeds chaos, but it also creates conditions for the inception of an ambitious social plan. Importantly, this plan is less connected with the strategic decisions made on the political level than with grassroots activity, as it is an expression of the natural needs and intuitions of the people who fully see the chances that the new political situation has brought about. In a word, My Sweet Pepper Land eulogizes the rudimentary values of liberalism, with its insistence on civil liberties, tolerance and neutrality. As Andrew Levine puts it, "[a] position is liberal... if it marks off an area of individuals' lives and behaviors as immune from state and also societal interference - in other words, if it accords individual rights against the state and society" (56). At the same time, the institutional apparatus of the state is responsible for ensuring that the exercise of individual freedom does not violate pre-defined norms: "Within their own private spheres, individuals may be as ardent as they please in the pursuit of their own conceptions of the good. Deep commitments and overt partisanship may carry over into the public arena, too - subject, however, to constitutional constraints" (59). My Sweet Pepper Land emphasizes the naturalness of civil liberty, which emerges as an element of some kind of universal legacy, and at the same time it looks into the cultural factors that 
hinder the crystallization of liberal attitudes. The film has a discernible pedagogical subtext: the way to the accomplishment of a liberal utopia leads through education, a prerequisite for overcoming age-old structures of privilege and injustice.

Among the observers of the execution there is Baran (Korkmaz Arslan), the film's protagonist, a former Kurdish "fighter," as he calls himself, who needs to find a place for himself in the new reality. What he witnesses during the execution convinces him that he does not want to serve the emergent state, and he refuses to stay in the army, but when he returns to his mother, he soon finds out that family life is not for him, either. Therefore he eventually accepts the post of a police chief in a distant village in the North, near the Turkish and Iranian borders. There he meets Govend (Golshifteh Farahani), a teacher whom he supports when the villagers try to remove her from her job; predictably enough, Baran and Govend become lovers. The village is dominated by Aziz (Tarik Akreyî), the head of a powerful local clan and the leader of a gang of smugglers. He wants to corrupt and subordinate Baran, but the latter resists him and declares that he will enforce the rule of the law. The tension between the police chief and the smugglers escalates, and a final confrontation becomes inevitable. Interestingly enough, it is provoked by a group of female guerillas who have been attacked by Aziz's men. The armed women come to the village and ambush Aziz in his house in an act of retaliation; however, they only wound him, and Baran has to finish what they have begun. The use of the Western genre in My Sweet Pepper Land has a characteristic simplifying effect in suggesting an easy solution to a complex cultural conflict. There are "the goodies" and "the badies," and two opposing systems of values which the sides of the conflict subscribe to. The victory of one side is to be accomplished through the elimination of the other. There is some room for the negotiation of values, but the winning party decides about its extent. The logic of the genre makes liberalism appear to be the only valid basis for the organization of the new nation, hence the impression of the obviousness of such a choice.

Baran's similarity to the archetypal hero known from Westerns is increasingly visible from the moment he refuses to return his gun upon ending military service. This is an early sign that he accepts violence as a way of solving problems if the circumstances justify such a last resort. He cherishes his personal independence, and at the same time he readily commits himself to the well-being of others. The fact that he has witnessed a failure of legal proceedings does not undermine his faith in the law; perhaps, on the contrary, it makes his respect for it and determination to enforce it even stronger. Baran arrives at the village on horseback, having abandoned his car when he learnt that the only bridge leading to the village had been destroyed. The switch from the car to the horse underlines the hero's passage into the borderland. Baran's lineage as a type of character becomes evident with the scene of his first serious verbal confrontation with Aziz. The gangster is testing the policeman's willingness to collaborate and tells him: "There are laws written and there are ancestral laws," to which Baran replies: "Laws should apply everywhere. It is I who must enforce it." What 
comes next is a declaration of embodiment, which immediately brings to mind a host of sheriffs in classic American Westerns: "I am the law," says Baran, the words that signify a radical rejection of everything that Aziz stands for. Baran's similarity to the Western hero is an element of a larger process of Westernization that he undergoes so as to emerge as an agent of liberal change. Importantly, we learn next to nothing about Baran's past, for example whether he had been exposed to some kind of influence that instilled liberal convictions in him. Such an omission suggests that his attitude has evolved freely as an expression of how he normally thinks of himself in relation to others. His spontaneity is meaningfully shown in a shot in which, while driving his car, Baran is listening to and singing an Elvis Presley song. His spontaneity thus manifests itself through attachment to a particular achievement of Western culture.

That Baran and Govend complement each other is evident from two alternating sequences at the beginning of the film, showing the two characters in family situations in which the traditional models of family life have been depicted as relics or constraints. In Baran's case, this problem is introduced in a humorous way: soon after his return home, his loving mother turns into a matchmaker and invites one by one several candidates for a wife, none of whom strikes one as particularly attractive. Obviously enough, Baran cannot treat his mother's efforts seriously, which hints at his general perception of the gender-specific duties dictated by the tradition - he is not going to live up to them. The circumstances in which we initially see Govend are rather dramatic and cause her anxiety: there is a gathering of the men in the family, including her fiancé, who will decide whether she will be allowed to go back to the village and resume her work as a teacher. Some of the men, especially Govend's father, seem to be split between a personal understanding of her choice and the demands of the tradition regarding female activity, and none of them supports her with full conviction. In the end, however, they allow her to go. The cuts between the sequences dedicated to Baran and to Govend suggest a strong affinity between the two characters and anticipate their meeting and subsequent relationship. Both Baran and Govend have returned home and quickly want to leave it again, their alienation from the families attesting to the personal changes they have experienced. An important symbolic expression of the closeness of the two main characters is music: Baran sings a Presley song, and Govend plays the hangdrum, an instrument that has a recent Swiss origin, but its sound serves in the film a medium of so-called world music. Later on, during one of their talks, she asks him about his favorite kinds of music, and Baran answers: Bach and Mozart. Thus, through his preference for rock'n'roll, on the one hand, and classical music, on the other, Baran embraces the cultural legacy of the West as his own. Popular music, classical music, and hangdrum compositions yield a cultural fusion which the film appears to advocate. It is worth mentioning that the role of music in the film is further enhanced by the soundtrack composed by the French band L'Attirail and combining various transnational genres and influences into harmonious wholes. 
My Sweet Pepper Land explores the ideological and emotional dimensions of the conflict between modernization and tradition. This conflict affects communal life as well as much more intimate interhuman relations. Modernization seems to be the only possible direction of development, but the tradition is a powerful force that hinders the modernizing process. In the communal realm, the conflict manifests itself through a temporary coexistence of emergent state institutions and entrenched clan structures. Institutions promote the ethos of public service, whereas clans defend the ethos of group loyalty. The tradition sanctions various forms of an individual's dependence on and subordination to others, and it is not easy to repudiate it not only because it instills in the people's minds the fear of worthlessness and powerlessness if they lose the support of others, but also because it helps fulfill certain emotional needs. This is best shown when, on a few occasions, Govend plays the hangdrum amidst the landscape to assuage her anxiety. As a matter of fact, the heroine's attachment to the European instrument, on the one hand, and to the place where she has lived and worked, on the other, proves that the tradition will continue to inspire the people in the modernized reality if they learn to draw from it selectively. The tradition as a whole inevitably signifies resistance to change, and a metaphor of this is the destroyed bridge that separates the village from the rest of the world instead of connecting it to it. In personal terms, the conflict between modernization and tradition is reflected in the contrast between the values of dignity and honor. Honor forces one to constantly envisage oneself as seen through the eyes of others, while dignity is tantamount to a gradual, unconditional recognition of self-worth. The clash of the values of honor and dignity is best illustrated by a scene toward the end in which Govend's brothers and fiancé come to the village to punish her for having an affair with Baran. The woman is brutalized, but the violent event, despite a poignant outcome, ultimately reaffirms her independence.

The final confrontation between Baran and Aziz's gang testifies to the irreconcilability of the forces of modernization and the tendencies imposed by the tradition. It is symptomatic that the climactic sequence unfolds in an unspectacular way and, most importantly, there is no celebration of violence. The women fighters, who have been hiding in the mountains, attack Aziz who has sent his most trusted man to kill Baran at the police station, which hints at the alliance between the police chief and the guerilla women. The shooting at the police station is not shown on the screen: the gangster walks inside, the shots can be heard, then he walks outside backward and falls down. Baran immediately wants to settle the issue with Aziz whom he finds badly wounded at his place. The gangster reaches for his gun and provokes the police chief to shoot first; this act of self-defense seems to be tinged with pity. All in all, the killing perpetrated by Baran could perhaps be called "sanitized" insofar as it results from a sheer necessity and avoids excessive violence. Unlike American Western heroes featured in Shane-like scenarios, Baran does not assume collective guilt, a symbolic act that would place him beyond the margins of the community 
he has saved. Baran must stay in the community, become its new leader, and take responsibility for a renewal of social relations. At the end of the film, Baran and Govend, now standing by his side, reach the threshold of utopia: there is a better future ahead, and it is clear what kind of social organization it should be based on, but the difficult present reality casts doubt on the possibility of making this better future come true. In a word, the people are likely to resist change: a venal judge, a corrupted doctor who sells medications under the counter, and a cowardly school manager who will take orders from anybody who has power in the village are not good candidates for reformers. The elimination of corruption will not change much, it can only be a first step in the process of creating new ways of thinking - and this is why Govend the teacher plays such a crucial role. The liberal utopia is to be achieved through education. Baran and Govend do not delude themselves about the true beliefs of the older villagers who share Aziz's mentality, but place their hope in the children who have seen that things can change.

\section{THE UTOPIA OF SOVEREIGNTY}

While My Sweet Pepper Land carries a serious political and cultural message - whether the course of development it postulates is viable or not - Dust looks at the issues of history and politics from an ironic distance and approaches them in a playful manner. This playfulness has to do with the employment of a variety of postmodern cinematic techniques. The film introduces two temporal planes which not only alternate, but repeatedly intersect, producing an obvious anachronistic effect. In this way, Dust points to the process of historical reconstruction as a highly arbitrary one, dependent on factors that are not always verifiable, and puts stress on the role of imagination and invention in understanding the past. The film displays an ironic consciousness of its own ideological subtexts. Furthermore, Dust directs the viewer's attention to the artificiality of its form: while the convention of the Western constitutes the narrative vehicle of the film, it has been combined with a contemporary social drama, a historical account and a fairy tale of sorts. The film undermines the logic of narrative mediation by introducing the figure of a teller, through whose story the past enters the plot, and then removing that figure - by having her die before the culmination of the historical events evoked on the screen. The culminating sequence thus has its source in the convention, and not in the original story. By placing American Western heroes in a Macedonian setting, a rather outlandish idea in itself, Dust acknowledges a lasting global appeal of the Western genre. The postmodern celebration of formal solutions that characterizes Milcho Manchevki's film does not completely obscure its political dimension, centered on the notion of sovereignty. Just as My Sweet Pepper Land reduces liberalism to a presumed recognizable essence, Dust equates sovereignty with territorial independence. Joseph Camilleri 
writes: "the sovereignty discourse, as traditionally understood, implies first and foremost a way of defining and exercising politico-legal authority within clearly demarcated boundaries;" this is a necessary condition for "conceiv[ing] of sovereignty as a way of partitioning the world, of allocating resources and organizing exchanges between states and national economies, of distinguishing groups, cultures and nations" (35). Understandably enough, Dust concentrates on the fight for freedom and leaves aside all the questions regarding the formation of "politico-legal authority." Its utopian aspect - even if articulated only half-seriously — has to do with the belief that freedom, as it is manifested through territorial sovereignty and self-governance, guarantees a better future for the nation. The film reveals the illusions behind such thinking and specifically ponders what the sovereignty of a small nation means on a global arena of power relations.

Dust employs two temporal frames: a contemporary and a historical one. The contemporary subplot features a young African American nicknamed Edge (Adrian Lester) who becomes involved in an unusual friendship with an elderly white woman named Angela (Rosemary Murphy) whom he has tried to rob. Having broken into a randomly chosen apartment and rummaged around the kitchen, Edge is suddenly faced with the owner who is pointing a colt gun at him. However, she does not intend to hand him over to the police; instead, she persuades him to listen to her story and even promises him a reward if he does. The historical subplot is thus ushered in: it is the beginning of the twentieth century, and two American brothers, Elijah (Joseph Fiennes) and Luke (David Wenham), fall out with each other after the latter has seduced the former's wife (Anne Brochet). Luke leaves for Europe, and soon after that Elijah sets out on a chase after him to avenge the wife who committed suicide. Luke ends up in Macedonia where he joins a gang of bounty hunters. The Turks, who occupy the region, have offered a big reward for the head of a dangerous rebel who goes by the name of Teacher (Vlado Jovanovski), and Luke is determined to pursue him, but he begins to hesitate after meeting the Teacher's beautiful wife Neda (Nikolina Kujaca). The woman is pregnant, but her mind is set on the cause her husband has been fighting for. She talks a lot about the necessity to confront the oppressors, and in this way she forces Luke to think - for the first time - about the moral consequences of his actions. The brothers' paths eventually cross: they have a fight in a mountainous scenery and it is Luke who wins, but Elijah nevertheless makes him admit to all the evil he has been guilty of. Therefore when Luke returns to the Teacher's village, he is a changed man, ready to sacrifice himself for the sake of the weak. In the meantime, the Turks have raided the village and killed Teacher, and are now celebrating their victory. Luke reaches for his gun and instantly kills some of the Turkish commanders and, as the shooting continues, more and more villagers join him with their weapons. In the end, Luke dies of wounds, and so does Neda, who has given birth to a child before passing. Elijah comes to the village and carries away the infant. 
Similarly to My Sweet Pepper Land, Dust depicts a time of transition, albeit of a markedly different kind: from the mythical to the historical era. Angela describes Macedonia at the beginning of the twentieth century to Edge with the following words: "[Luke] took up his old job, killing for money... Then moved to the last frontier, far from the Wild West, the Wild East, where the centuries do not follow one another, they coexist." The Wild East, although it has a specific geographical location, resembles a fairy-tale-like setting where an uncontrollable force has wreaked havoc: "Over two hundred gangs roamed the Macedonian countryside... Some fought for freedom, some fought for land, some fought for God, but everybody loved gold." Early on in the film, the mythical aura clashes with the evocations of the historical context; when Edge rummages through Angela's belongings, he comes across a box with newspaper clippings dating from 1903, the year of the Macedonian uprising against the Turks, and the headlines read: "Greeks betray Macedonians," "Anarchy in Macedonia," and "50,000 killed by Turks." One may suggest that the movement toward sovereignty is a sign of the transition from the mythical into the historical era. The situation shown in Dust, in a way, parallels the outcome of the process which Benedict Anderson, in his seminal book Imagined Communities, describes as the dissolution of the dynastic realm, which, in his opinion, was one of the key factors behind the emergence of modern nations. Anderson juxtaposes kingship with state sovereignty: the former "organizes everything around a high centre," whereas the latter "is fully, flatly, and evenly operatic over each square centimetre of a legally demarcated territory." When rulers embodied the utmost concentration of power, "borders were porous and indistinct and sovereignties faded imperceptibly into one another." This allowed "pre-modern empires and kingdoms... to sustain their rule over immensely heterogeneous, and often not even contiguous, populations for long periods of time" (19). It would be a misunderstanding to assume that an ironic, self-reflexive film like Dust aspires to reveal something crucial about the nature of historical process; however, it does take up the problem of the narrative mediation of history. It employs myth to reduce history to a very basic conflict, and this results in conveying a purely one-dimensional idea of sovereignty.

While My Sweet Pepper Land conceives of a utopia that has a concrete ideological frame, Dust puts forth a vague utopian vision. In a word, the utopia envisaged in the Macedonian Western is tantamount to a pastoral idyll. The viewer gets a few glimpses of what the ideal life of a sovereign community looks like from the sequence that shows Luke's recuperation after he had been wounded. We see a group of women doing the washing and a bunch of boys bathing in the stream. The villagers work together, pray together, and play games together, and, accordingly, sovereignty becomes an experiential community value. Furthermore, sovereignty is equated with communal self-sufficiency, therefore it entails a form of isolationism on a micro-scale. This aspect is symbolically emphasized by the location of the village in the mountains and the fact that only one passage leads to the settlement. 
It can be surmised that the people there live in accordance with the laws of nature, which is the source of their moral strength. The Turkish soldiers, on the other hand, stand not only for oppression, but also for contamination, which marks them as morally corrupt. The utopia of sovereignty thus depends on obvious oversimplifications, and it comes as no surprise that the film casts doubt on the ideas behind it by undermining the foundational myth of "the nation." The myth is a sacrificial one: Teacher and Neda have to die for the courage of the people, their deeply felt longing for freedom - in a word, their spirit - to be awakened. However, a question arises as to who will take over the leadership. Traditionally, the child of the symbolic father and mother of the nation is destined for this task, but such a logical denouement is not to be found in Dust. To begin with, the child is a female, and this complicates matters because foundational national myths tend to be gender-specific and to foreground male experience. More importantly, as a result of Elijah's interference, the child disappears from the community as if, speaking bluntly, she deserved better. Admittedly, the villagers have discovered their collective agency, but the question remains as to their ability to exercise it.

The villagers gain assurance as to their collective agency thanks to the impact of a powerful stimulus, which - meaningfully — is not the Teacher's death, but the intervention undertaken by Luke, the American savior of the oppressed Macedonians. Dust can thus be interpreted as an allegory of American interventionism. It alludes to certain ambivalent aspects of U.S. interventionist policies, but ultimately implies that the expected benefits outnumber the possible risks. In the beginning, Luke pursues very selfish goals, just as American interventionism often appears crude and myopic before bringing the desired results. Luke turns out to be capable of moral regeneration, and he comes to understand the necessity of taking action for the sake of others. His transformation on the mountain carries deeply spiritual connotations. Likewise, interventionism can be redeemed on moral grounds if it targets evident cases of abusive rule. The theme of intervention further brings out the utopianism of the dreams of sovereignty. When Luke starts the final shooting, the men in the village join him in the fight after a while, then the women reach for weapons. Finally, a small boy raises a gun and aims at the Turk who has just shot Luke. The point is that the villagers begin to fight in reaction to what has been going on before their eyes, and not out of their own conviction and initiative. They only act within the limits that others - those who possess greater power - have determined. It is not completely unlikely that the villagers would more gladly remain observers rather than turn into fighters, a role that has been imposed on them by the circumstances. When the shooting breaks out, they look confused and hesitant at first, and when they take up the fight it is as if they felt compelled to live up to their own heroic imaginings of themselves and to follow the imperative which Neda best verbalized in her talk with Luke: "Kill for the people. Fight for freedom. For good... Kill for tomorrow." There is an ambivalence about the people's behavior that might be a sign that they have not completely renounced 
pragmatism in their pursuit of a utopia. The war in which their fate is at stake is being waged by the powers much more potent than they are - such is the logic of the historical process. The final liberation of the village confirms the contingency of sovereignty and undermines the utopia to which it purportedly opens a door.

The utopianism of sovereignty is not necessarily a reason for despair. As Joseph M. Colomer observes in his book Great Empires, Small Nations, "small democratic governments" benefit from the existence of "very large areas of "imperial' size, which provide public goods, such as defense, security, trade agreements, common currencies and communication networks" (xi). He anticipates the advent of a time when "the difference between formal independence and autonomy for small nations will be merely a question of degree" because it is already possible for "a small community's self-government" to function "without having its own army, borders or customs, without having a sovereign state" (xi). Small nations avoid "the heavy burdens of classical statehood" and smoothly merge with "an open international environment" (19). These comments made by a contemporary political studies scholar may seem at first to be somewhat wide of the mark in reference to the historical situation presented in Dust, but they capture the ideological message of the film. By narratively connecting history and the present time, the film looks at the emergence of networks that bind nations through the varied forms of exchange. This course of development is shown on the example of what happens to the money that had been collected to support Teacher and his men. First stolen by Luke, and then carried away to America by Elijah, a sack full of coins has remained hidden for almost a century. But a time comes to remove the money and put it to good use when Edge finds himself in trouble, having been unable to pay off the debts he owes the local gangsters. He repays the late Angela by taking her ashes to her native land. In the image with which the film ends, the plane with Edge aboard appears in the sky over Elijah as he is riding away with the infant.

\section{THE UTOPIA OF ENFRANCHISEMENT}

Blackthorn employs the convention of the historical Western to address the lasting problem of neocolonial exploitation. As Robert J.C. Young puts it, "[n]eocolonialism denotes a continuing economic hegemony that means that the postcolonial state remains in a situation of dependence on its former masters, and that the former masters continue to act in a colonialist manner towards formerly colonized states" (45). Young stresses the fact that the examination of neocolonial practices invariably focuses on the cultural mechanisms that condition economic regimes:

The term "neocolonialism" remains useful in that it insists on a primarily economic account of the postcolonial system from a broadly Marxist perspective. It has allowed writers and activists... to develop a cultural and political analysis which, within the framework of the economic 
argument, lays emphasis on related continuing cultural effects such as cultural dominance, often perpetuated by the continuing presence of descendants of settlers, of the endurance of colonial languages... as a de facto national language, or of westernized educational, legal and political institutions that were originally set up during the period of colonization. (48)

Blackthorn puts forth a solution to neocolonial injustice: the enfranchisement of the groups that have experienced oppression and exploitation, especially the poor and the indigenous, through ownership. This is a utopian postulate insofar as it finds an easy way out of a very complex situation, disregarding a variety of interconnected factors that have led to the strengthening of an unjust system. Admittedly, in this respect, Blackthorn does not differ significantly from My Sweet Pepper Land and Dust. A utopian belief results from anger and anxiety as much as from naivety, and Blackthorn shows the irony of emotions that underlie utopian longings perhaps more directly than the other two films under discussion. Just as Dust suggests that the sovereign rule of small nations depends on the will of global powers, Blackthorn implies that the enfranchisement of the underprivileged depends on the concessions which those who enjoy the privileges are ready do make. While ownership appears to be as tangible a social fact as it only can be, it also substantiates a powerful social fantasy. And sometimes the fantasy - the promise, the prospect - suffices to satisfy the people. In Blackthorn, the victims of economic injustice are allowed to entertain such a fantasy, without actually effecting any changes in the social system that sustains the existing forms of exploitation. No matter how strongly they cling to the illusion, they are bound to face the crude facts of life again sooner rather than later.

Blackthorn is a variation on the story of Butch Cassidy and the Sundance Kid. It's the year 1927; Butch Cassidy (Sam Shepard), now an elderly man, lives in Bolivia under the name James Blackthorn and makes his living from breeding horses. He has been planning on going back to the United States and moving in with his nephew - who actually is likely enough to be his son - therefore he sells all his horses and collects his savings from the bank. On the way from the town to his house in the mountains, he is attacked by a man who wants to take away his horse, and although he fights back and defeats the assailant, he loses the horse and the money. The assailant is a Spaniard by the name of Eduardo Apadaca (Eduardo Noriega); he confesses to Blackthorn that he has stolen money from the owner of a silver mine and promises to compensate Blackthorn for his loss if he helps him recover the money Eduardo had hidden in the mine. After collecting the money, they have to run away because a posse has been sent after the Spaniard. Blackthorn and Apadaca decide to split up, and the former, after an exhausting ride through the salt desert, gets to a town where he is recognized by an American named Mackinley (Stephen Rea), once a Pinkerton agent and now an honorary consul in Bolivia. Mackinley informs Blackthorn that the ownership of the mine has been granted to the Indian miners after their rebellion against the cruel owner, and it is they who have been robbed. After a short period of 
convalescence, Blackthorn rides off in search of Apadaca, and when he catches up with him he wounds him and leaves him immobile, in this way enabling the miners in the posse not only to regain their money, but also to bring the thief to justice.

Curiously enough, for a film that advocates the struggle for enfranchisement, Blackthorn noticeably limits the role of the enfranchised ones in the plot. Similarly to Dust, the conflict in which the life of "the people" is at stake is enacted here by those who do not belong among "the people." The miners do not have a true leader who would not only be one of the driving forces behind the film's action, but also - literally and symbolically — would speak for his people. As a matter of fact, the miners hardly ever talk in the film. There is a scene in which one of the miners who have formed the posse (Luis Aduviri) catches up with Apadaca and, assuming that he is too weak to defend himself, he starts to talk about his unforgivable betrayal. As it turns out, they were friends once, but Apadaca ruined everything, or perhaps he had been acting deceptively from the beginning. The point is that this scene, in which the miners' concerns and feelings are directly articulated by one of them, reduces the problem of exploitation to a personal grudge. It is worth comparing briefly Blackthorn with an acclaimed Spanish production Even the Rain (Icíar Bollaín, 2010), which also uses the Bolivian setting and deals with the issue of exploitation. A Spanish film crew comes to Bolivia to shoot a series of scenes for a film about Christopher Columbus and the beginning of the conquest of Mexico. They employ a group of local indigenous people to play the Indians in the film and offer them minimum wages. Among the hired locals there is a man named Daniel (Juan Carlos Aduviri) who becomes a self-appointed spokesman for the whole group and demands better working conditions and - no less importantly — respect from the Europeans. Initially irritated by Daniel's insubordination, the filmmakers begin to show concern about his situation and the miserable life conditions of the people whom he represents, and gradually it dawns on them that they have unknowingly been a part of a global distribution of privilege and injustice. The whole cruelty of the system becomes apparent to them when a riot breaks out in the town in reaction to the announcement of the privatization of water supply, which will inevitably lead to the increase of the price of water. Even the Rain ends on a very pessimistic note as it suggests that nothing is going to change: the Spaniards go home, the Bolivian poor are left to themselves. In the light of the crude facts of disfranchisement shown in Even the Rain, the promise of enfranchisement envisaged in Blackthorn reveals its utopian nature. It is also very symptomatic that Blackthorn ascribes a moral and emotional force - which in Even the Rain is embodied by an indigenous character - to an American hero. Blackthorn conveys a populist message that Deus-exmachina solutions to the most serious social problems really exist.

Despite the narrowing down of the miners' presence in the film, one can point out a few scenes that attest to their empowerment. The first such scene is the attack of two Indian women on Blackthorn's place where Apadaca is briefly staying; 
they shoot to death Blackthorn's Indian mistress and wound him before they are themselves killed. This is a puzzling event — for Blackthorn and the viewer alike - because the situation in the mine has not been explained yet. In other words, the reason for the women's aggression remains unknown at this point in the plot. What happens in the aftermath of the fight provides the first indication that the Spaniard's intentions are insincere: he drops the bodies of all three dead women into the river, and then tells Blackthorn that he has buried his beloved, pointing to what looks like a fresh grave. Another sign of the empowerment of the miners is a series of the shots of the posse, especially the most spectacular ones, showing the ride through the salt desert. Again, at this point in the film, the viewer still doesn't know about the change of ownership in the mine. One is likely to assume that the men in the posse are gunmen who have been hired by the mine owner to do a predictable job. Since the pursuers are Indians, the suggestion is that the indigene simply play by the rules of powerful white men. The delayed revelation of what happened in the mine is key for keeping up narrative tension, but it results in placing the Indians in roles which - for a good part of the film - appear unnatural: aggressors and mercenaries. From this, we can derive an implication that the enfranchisement of the Indians is not a fully natural thing, either. The last scene that proves the empowerment of the miners takes place in the conclusion of the film: accompanied by the soldiers, who have embarked on a search after Apadaca as well as Blackthorn/Cassidy, the miners find the wounded Spaniard and regain their money. The soldiers' presence is of crucial importance as it suggests a new union of classes and a new standard of protection of the underprivileged. One of the Indians proudly and happily raises the sack with money as if he craved recognition in the soldiers' eyes. The union of the miners and the soldiers is a utopian course of development, and the paths of the two groups diverge immediately because the latter have not completed their mission. They are more eager to catch a legendary American bandit than an anonymous Spanish fraud. In one of the closing scenes, the officer in charge of the soldiers approaches Mackinley, who has come with them, and tells him that he is taking away his horse as a punishment for helping Blackthorn. In all likelihood, the consul will perish in the mountains. Therefore, as the film ends, the drama of a white man resounds with a much greater force than the presumed victory of the Indians.

The motif of the chase inverts the paradigm of power relations within the colonial regime. The film ironically portrays Apadaca as an heir to the legacy of Spanish colonizers through Blackthorn's allusions to the Spaniard's noble origin: on one occasion, he calls him "a conquistador," and on another he says: "Never rode with a gentleman before. Never hoped that I would." The theft of money from the Indians is a rather embarrassing manifestation of the colonizer's greed. In Blackthorn, the responsibility for all the wrongs of the colonial rule falls onto Apadaca, and his crime is the proof of downright moral degradation. For Mackinley and Blackthorn, the Spaniard's lack of scruples is simply unimaginable; the former says to the latter: "In my day the out- 
laws would have robbed banks. And the Union Pacific! They would never have stolen from the mining families." Apadaca's immorality signifies the utter bankruptcy of colonialism. Furthermore, the placement of the colonizer in the role of the fugitive, and of the colonized in the role of his pursuers, metaphorizes the necessity of a thorough reorganization of the social structure of the former colony. However, the film essentially depicts a change that has taken place in the sphere of social symbols, leaving open the question whether it will lead to a noticeable and lasting reconfiguration of the real relations of power. The film's greatest ambivalence has to do with the fact that it almost completely leaves out the class of owners. Of course, there is some talk about the mine owner who has transferred the ownership title onto the miners, but neither he nor anybody else from his class appears on the screen. This is a crucial omission because it is this class that decides about the extent of the enfranchisement of the underprivileged. As a matter of fact, the granting of ownership right to the miners is an experiment of sorts which is not costly - the resources of the mine have been running out - and which can bring about a desired effect in quenching the miners' rebellious spirit. The only risk that this experiment entails is that the illusory right will allow the Indians to believe that they are in a position to demand real rights.

The two American characters in the film - Blackthorn and Mackinley - emerge as spokesmen for the enfranchised Indian miners. Mackinley tells Blackthorn about the change of ownership in the mine: "The miners rebelled against the owners. Overdue wages, murders... The usual... There was a huge battle. A lot of miners were killed. Then Justice stepped in and, this country is full of surprises, they decided in favor of the miners. They awarded ownership of the mine to the surviving families... The mine was almost empty." Blackthorn reacts to this revelation with utmost bewilderment, and he immediately realizes that he has offered help to a criminal who acted just despicably. Mackinley sees the expression of guilty conscience on Blackthorn's face and adds: "There are times you would prefer to be dead." This sentence actually defines both Americans as men who have been destined to defend the moral order despite their withdrawn attitudes. They may not have achieved much in their lives, but they have retained a strong sense of justice; in a way, the lack of achievement underlies their disinterested motivation. Their high moral standards that make them the only true defenders of the Indians are emphasized through contrast with the Spaniard's understanding of the circumstances in the scene in which Blackthorn, having caught up with Apadaca, demands an explanation from him:

Apadaca: It [the mine] had different owners. Owners anyway.

Blackthorn: You never did see the difference, did you?

Apadaca: For the Indians? For a bunch of miners? For them? And what about me?

The Spaniard speaks about ownership as if it were morally flawed by definition and he naturally deserved to be exculpated. His words resound with extreme egoism combined with a conviction of racial superiority. In Westerns, the antagonist often 
provokes the protagonist to reach for the gun for the very last time and settle the issue for good, but such a culmination is not to be found in Blackthorn. Blackthorn leaves Apadaca immobile, but alive, in the mountains, knowing that the posse is approaching. This is an important solution in the plot, suggesting the possibility of further enfranchisement of the Indians through their more direct involvement in the execution of the law. The Indian men in the posse do not show any determination to punish the Spaniard on the spot; apparently, they are ready to embrace the system of the law, if it assures them proper recognition. It should be remembered, though, that it is Blackthorn who catalyzes this utopian change.

\section{CONCLUSION}

In their introduction to the collection of essays International Westerns: Re-Locating the Frontier, Cynthia J. Miller and A. Bowdoin Van Riper write:

The icons and themes of the classic American Western belong to a particular moment in U.S. history, and it addresses the issues and processes that were, in that moment, defining the nation and its culture. Those issues - imperialism, industrialization, the relationship between individual and community, and the rights of indigenous peoples - are not, however, unique to the United States or to the late nineteenth century. They were, and are, part of the shared experience of all expansionist nations, and the international appeal of the Western rests, in part, on the potential for the historical experiences of one culture to resonate with audiences from another. (xiv)

As the three transnational Westerns discussed here prove, the genre appeals with virtually equal power to the "expansionist nations" and the nations that have experienced some form of colonization. The archetypes and topoi created by the Western are larger than the historical contexts in which they have been instantiated. This accounts for the continuing relevance and extraordinary adaptability of the convention. As a result of its reliance on archetypal variants of the plot, the Western acquires an affective quality which helps to channel the expectations and emotions of different national audiences. The presence of utopian subtexts in the three films presented in this article allows us to understand how this affective potential is generated depending on socio-political conditions and how it shapes the ideologized cultural functions of transnational Westerns today.

\section{WORKS CITED}

Anderson, Benedict. Imagined Communities: Reflections on the Origin and Spread of Nationalism. London: Verso, 1998. Print.

Camilleri, Joseph. "Sovereignty Discourse and Practice — Past and Future." Re-envisioning Sovereignty: The End of Westphalia? Ed. Trudy Jacobsen, Charles Samford and Ramesh Thakur. Aldershot: Ashgate, 2008. 33-49. Print. 
Colomer, Joseph M. Great Empires, Small Nations: The Uncertain Future of the Sovereign State. London and New York: Routledge, 2007. Print.

Hardt, Michael, and Antonio Negri. Empire. Cambridge, Mass.: Harvard University Press, 2001. Print.

Levine, Andrew. Rethinking Liberal Equality: From a 'Utopian' Point of View. Ithaca and London: Cornell University Press, 1998. Print.

Miller, Cynthia J., and A. Bowdoin Van Riper. "Introduction." International Westerns: Re-Locating the Frontier. Ed. Cynthia J. Miller and A. Bowdoin Van Riper. Lanham: Scarecrow Press, 2014. vi-xxviii. Print.

Slotkin, Richard. Gunfighter Nation: The Myth of the Frontier in Twentieth-Century America. New York: Harper Perennial, 1993. Print.

Tally, Robert T., Jr. Utopia in the Age of Globalization: Space, Representation, and the World-System. New York: Palgrave Macmillan, 2013. Print.

Wegner, Philip E. Imaginary Communities: Utopia, the Nation, and the Spatial Histories of Modernity. Berkeley, Los Angeles and London: University of California Press, 2002. Print.

Winter, Jay. Dreams of Peace and Freedom: Utopian Moments in the 20th Century. New Haven and London: Yale University Press, 2006. Print.

Young, Robert J.C. Postcolonialism: An Historical Introduction. Malden, Mass.: Blackwell, 2001. Print.

\title{
A MAP OF LONGINGS: UTOPIAN UNDERPINNINGS OF CONTEMPORARY TRANSNATIONAL WESTERNS
}

\author{
Summary
}

\begin{abstract}
Westerns evince utopian underpinnings when they highlight the necessity to reform corrupted social establishments and put forth solutions that are far from being realistic options. The genre usually depicts a microcosmic environment in which individual human vices, attesting to some kind of negative cultural norm, manifest themselves as excessive violence. Injustice and violence targeted at the grassroots calls for an immediate intervention, and that's what happens. The Western carries utopian implications in that it expresses faith in the possibility of a quick and deep change of the state of affairs. However, with the initial state of order having been ushered in, the Western narrative reaches its closure, and the accomplishment of the incipient utopia falls outside its narrative frame. The contemporary transnational significance of the Western has to do with the fact that it projects an allegory of positive change that can be applied to a variety of social and political contexts, and, at the same time, it precludes questions about the viability of the solutions it suggests. The article offers a reading of three post-2000 film Westerns with the aim to uncover their utopian senses. My Sweet Pepper Land (2013), advertised as a Kurdish Western, employs a familiar scenario wherein a lawman proves his courage and determination in the fight with a local clan. The hero embodies the longing for a modern, progressive social reality. Dust (2001), by using a historical Macedonian setting, addresses the issue of nation-formation. It introduces two American characters who function as catalysts in the process of a nation's transition from dependence to sovereignty. Blackthorn (2011) focuses on a historical situation in Bolivia to emphasize the problem of continuing neocolonial injustice. It seeks a solution to this in the enfranchisement of the groups that have experienced oppression and exploitation, especially the poor and the indigenous, through ownership.
\end{abstract}

Studia Filmoznawcze 38, 2017

(C) for this edition by CNS 


\title{
MAPA TĘSKNOT. UTOPIJNE FUNDAMENTY WSPÓŁCZESNYCH TRANSNARODOWYCH WESTERNÓW
}

\begin{abstract}
Streszczenie
Westerny przejawiają swoje utopijne fundamenty, gdy podkreślają konieczność zreformowania skorumpowanych społecznych elit i zastosowania rozwiązań, które są dalekie od realistycznych opcji. Gatunek ten zazwyczaj przedstawia mikrokosmos środowiska, w którym indywidualne ludzkie występki, potwierdzające jakiś rodzaj negatywnej kulturowej normy, manifestują się jako nadmierna przemoc. Niesprawiedliwość i przemoc dotykające zwykłych obywateli przywołują niezwłoczną interwencję, która następuje. Western przejawia swoje utopijne implikacje w tym, że wyraża wiarę w możliwość szybkiej i głębokiej zmiany stanu rzeczy. Jednakże wraz z wprowadzonym na początku stanem zasad opowiadanie westernowe dociera do swojego kresu, a wypełnienie rodzącej się utopii wykracza poza narracyjną ramę. Współczesna transnarodowa ranga westernu ma związek z faktem, iż projektuje on alegorię pozytywnej zmiany, możliwej do wprowadzenia w rozmaitych społecznych i politycznych kontekstach i że — jednocześnie — uniemożliwia odpowiedzi na pytania dotyczące wykonalności rozwiązań przez niego sugerowanych. Artykuł przedstawia interpretację trzech westernów filmowych XXI wieku, nastawioną na odkrycie ich utopijnych znaczeń. Pewnego razu na Dzikim Wschodzie (2013), reklamowany jako kurdyjski western, opiera się na znajomym scenariuszu, w którym człowiek prawa dowodzi swojej odwagi i determinacji w walce z miejscowym klanem. Bohater wciela tęsknotę za nowoczesnym, postępowym społeczeństwem. Proch i pył (2001), wykorzystując historyczną macedońską scenerię, dotyka zagadnienia formowania się narodu. Występują w nim dwaj amerykańscy bohaterowie, którzy działają jako katalizatory w procesie przechodzenia narodu od stanu podległości do suwerenności. Blackthorn (2011) koncentruje się na historycznej sytuacji w Boliwii w celu uwydatnienia problemu trwającej postkolonialnej niesprawiedliwości. Film sugeruje rozwiązanie go przez uwłaszczenie tych grup społecznych, które doświadczały opresji i eksploatacji, zwłaszcza biedaków i autochtonów.
\end{abstract}

Przet. Kordian Bobowski

Studia Filmoznawcze 38, 2017

(C) for this edition by CNS 